\title{
Computerised Accounting Software; A Curriculum that Enhances an Accounting Programme
}

\author{
Robert P Machera ${ }^{1, *}$, Precious C Machera² \\ ${ }^{1}$ Department of Accounting and Finance, Faculty of Business and Accounting, Botho University, Botswana \\ ${ }^{2}$ Department of Finance and Banking, Faculty of Business and Accounting, Imperial School of Business and Science, Botswana
}

Copyright $\subset 2017$ by authors, all rights reserved. Authors agree that this article remains permanently open access under the terms of the Creative Commons Attribution License 4.0 International License

\begin{abstract}
There has been an outcry in commerce and industry about students who fail to perform in the accounting department due to lack of "practical accounting skills". It is from this background that the researchers were motivated to investigate the impact of a Computerised Accounting Software Curriculum that enhances an Accounting Programme. At Botho University a degree in Bsc Hons in Accounting is offered and it is perceived that the graduates of this programme will be all rounded after completing this qualification. The Accounting programme at Botho University includes all the aspects that are needed for a novice accountant. However, the only shortcomings are the inclusion of a Computerised Accounting Software Curriculum into this Accounting Programme. It is believed that higher education students experience problems during their internship semester as they are expected to use Computerised Accounting Software. This study investigates whether the students at Botho University who are enrolled for the Bsc Hons in Accounting Programme face any
\end{abstract}

accounting software challenges during their internship period. The accounting software that students are expected to have knowledge include: spreadsheets software, quick-books and sage pastel accounting. Focus group and face to face interviews were used to collect data from students enrolled in the Bsc Hons in Accounting at Botho University Gaborone Campus, Maun and Francistown. The study focuses the students who were on the internship period. However the majority of the accounting students faces accounting software challenges and agreed that a Computerised accounting software curriculum should be proposed and implemented at Botho University in the Department of Accounting and Finance. This is done so in order to enhance the Accounting Programme and meets industry and commerce expectations.

Keywords Enhances, Curriculum, Spreadsheets, Quick- books and Sage Pastel Accounting

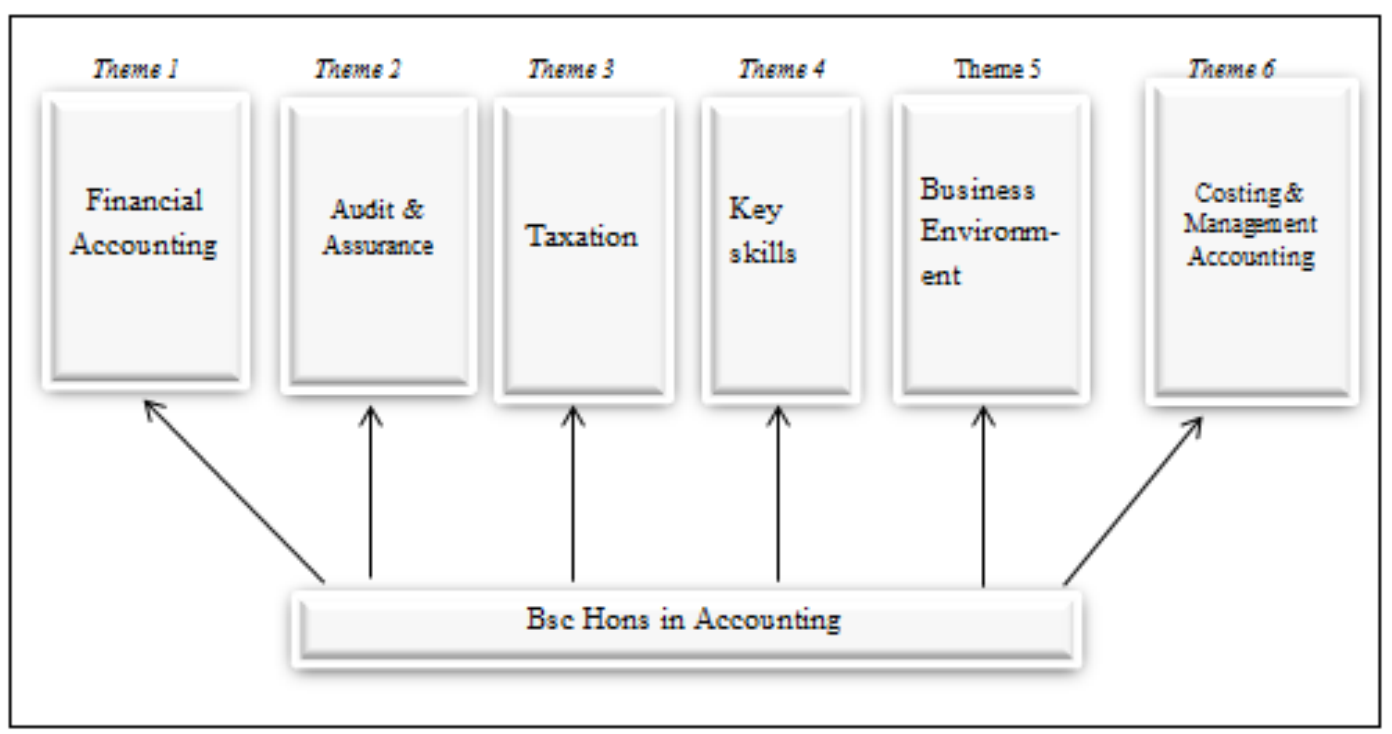

Figure 1. Themes for Bsc Hons in Accounting: Adapted from the researchers 


\section{Introduction}

The Faculty of Business and Accounting at Botho University offers a Bsc Hons in Accounting Programme that is very competitive in the region. The first cohort of students was enrolled in the Accounting programme at Botho University in July 2013. Currently the Accounting Programme is being offered in Botswana and Lesotho. This Accounting programme consists of six themes that include: financial accounting, cost and management accounting, taxation, audit and assurance, business environment and practical key skills. The Figure 1 represents a summarized thematic diagram for the Bsc Hons in Accounting Programme at Botho University.

The six themes form the basis of accounting pillars that mould the learners into competitive novice accountants. According to [8] a curriculum should strive to effectively deal with the modern world as this enhances the learners' competitiveness in the employment market. The Accounting programme at Botho links well with [8] philosophy, which includes four instincts such as: social, constructive, expressive and artistic. The themes in Figure 1 are the themes expected of any accounting programme, but the question is does it fit into the modern world? Any experienced accountant would agree with the above accounting themes and what is important is the competiveness of the programme. This paper focuses more on (key skills) theme 4 as this brings about the issues on outcome - based learning. Theme 4 is the backbone of the accounting programme as it reflects the skills that are needed by accountant in order to fit in an accounting environment. Modern employers require accounting graduates who are hands - on and self - starters as they have limited time and resources to invest into training and development [4]. In the context of Bsc Hons in Accounting, it appears that accounting students acquire key skills (theme 4) but the limitation in this theme 4 is learning on how to use the accounting software (packages). This research focuses on the following packages: spreadsheets, quick- books and Sage pastel accounting. The inclusion use of accounting software (packages) as a module is a serious gap in most Accounting Programmes hence it was imperative to investigate the need for computerized accounting curriculum. It was from this background that motivated the researchers to conduct this study.

[10] study report that accounting firms perceive that students with internship experiences and background are given much preference in the employment job market. Furthermore, [10] is of the opinion that there may be related changes in student's beliefs after participating in an internship program and this is a similar perception which was adopted in this study. According to [10] the following are traits that the student is expected to possess after the internship program:
1) Personality traits such as being personable or having a positive attitude

2) Technical / business traits such as analytical or accounting skills

3) Interpersonal skill traits such as communication skills and leadership

4) Background / other traits such as Grade Point Average (GPA), work experience and computer skills

This research targeted background / other traits such as GPA, work experience and computer skills since they are a challenge to be achieved by many undergraduate students. For example experience and knowledge of Computerised accounting may be difficult to be attained by undergraduate students since they would be at college. This study perceives these traits as paramount to accounting graduates. Computerised Accounting Packages have many benefits as shown in Table 1.

Table 1. Benefits for Computerised Accounting (Adapted from the researchers, 2016)

Benefits for Computerised Accounting:

- Easy to reconcile stock on hand

- Easy maintenance of asset registers

- Gives a provision for graphs and financial ratios

- Provides the business with financial intelligence

- Cloud accounting - online accounting (connectivity on smart phones, i-phones and use of internet

- Enhances speed for entry processing (e.g. add on module for bank manager)

- Enhances the rate for employability traits and selfreliance (consultancy)

- Enhances completeness and accurateness

\subsection{Commonly Used Accounting Software}

\subsubsection{Quick Books}

Quick Books is accounting software (package) that is used to process accounting transactions [21]. This software provides the user with the following features: chart of accounts, customised invoices, track accounts payable, track accounts receivable, profit and loss statement, balance sheet and manage cash flows. This software may be used by small businesses and medium sized entrepreneurs. The QuickBooks software provides the Quick Payroll Software, which is used in processing employee salaries. For more details about the technical features see [21]. However, the researchers are not licensed with QuickBooks in order to provide the some samples of the package.

\subsubsection{Sage Pastel Accounting}

Sage Pastel Accounting is accounting software (package) that is used to process accounting transactions [19]. This software has a payroll add on module which is used to process salaries. Sage Pastel Accounting software provides the user with the following features [19]: 
Chart of accounts: this is a list of all the accounting codes as for example:

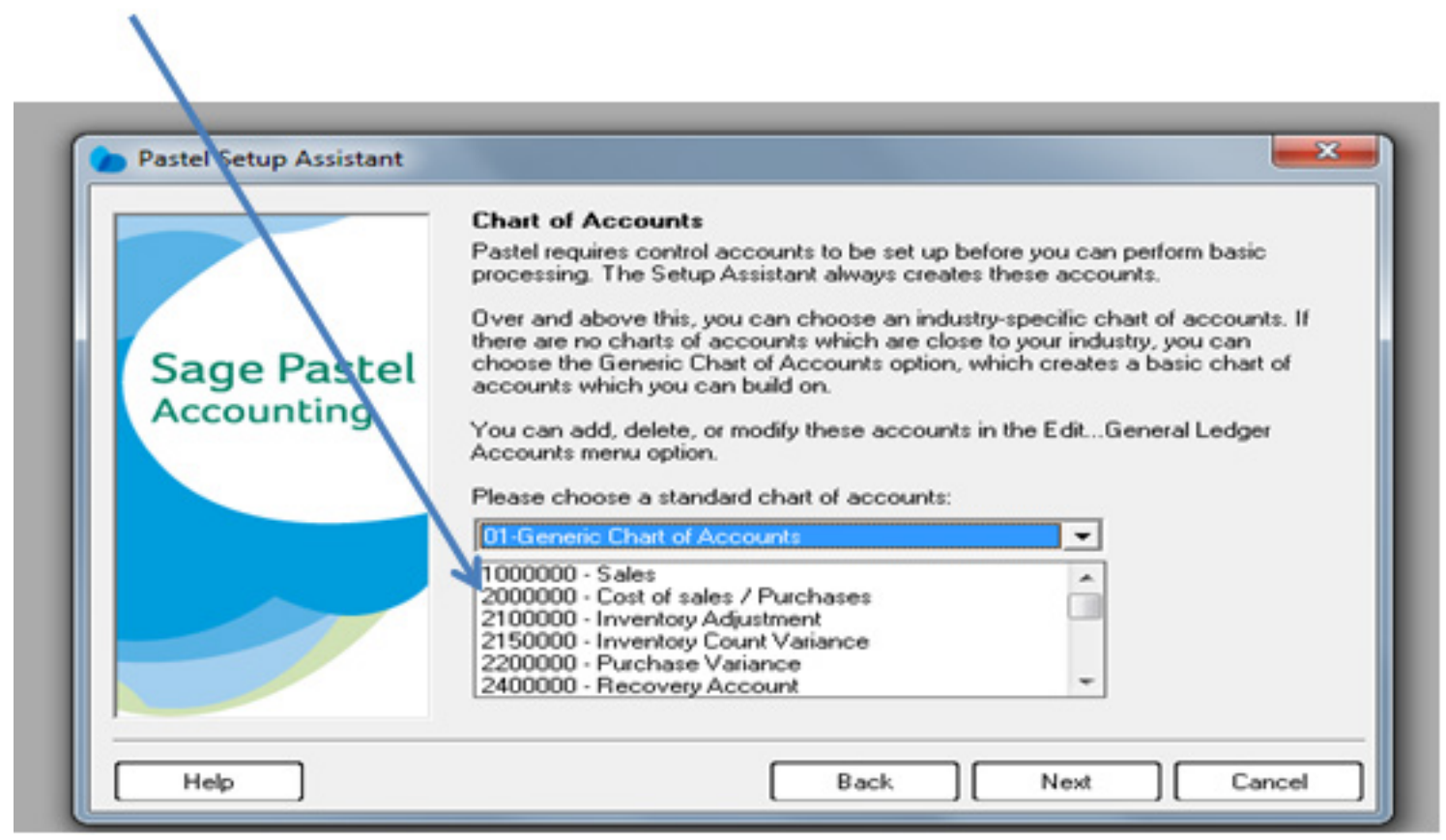

Process:

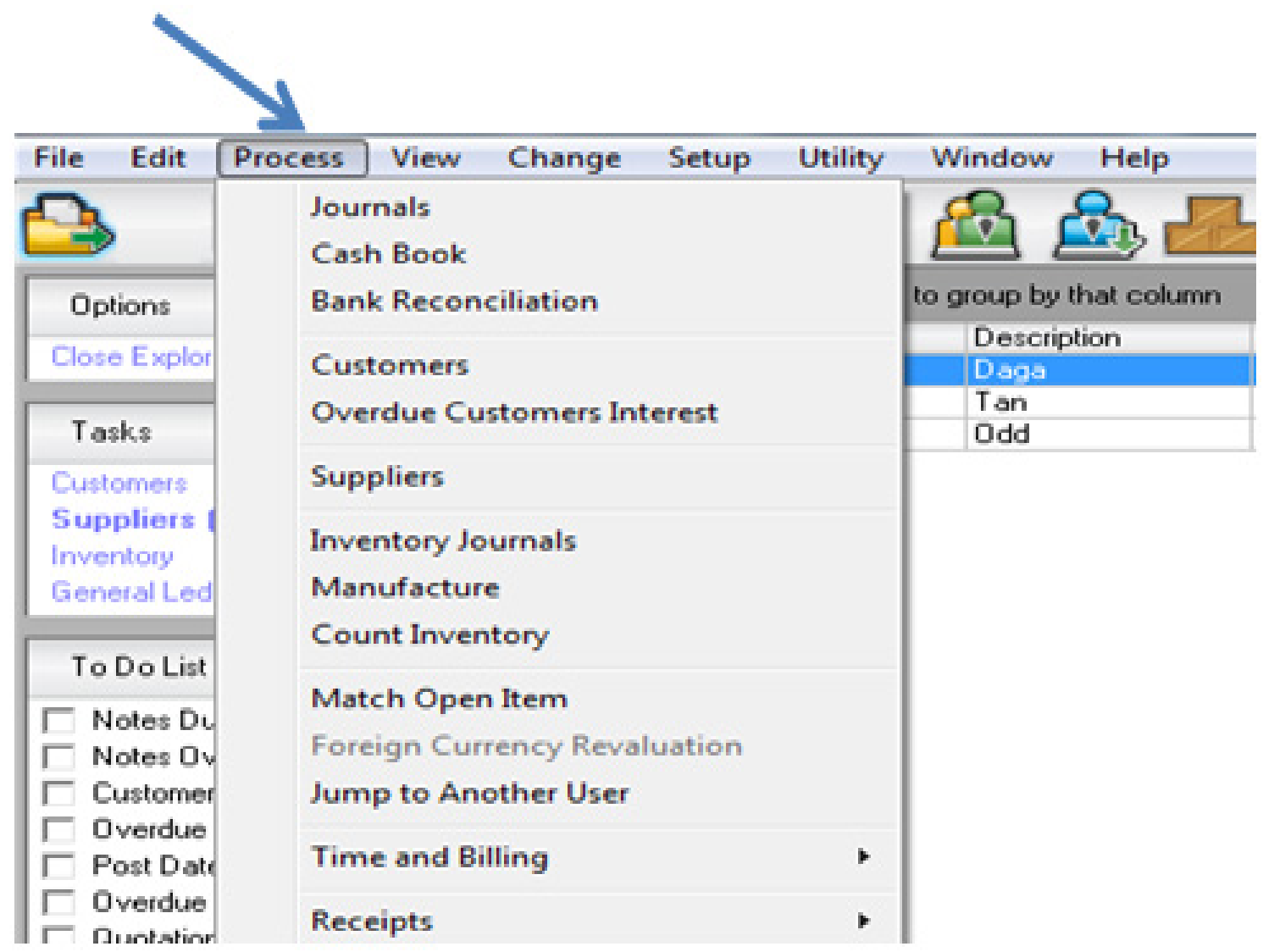

The process feature includes: the journals, cash book, bank reconciliation, customers, overdue customers interest, suppliers, inventory journals, manufacture, count inventory, match open item, time and billing and receipts. 
Trial Balance: The trial balance shows comparative figures from last year.

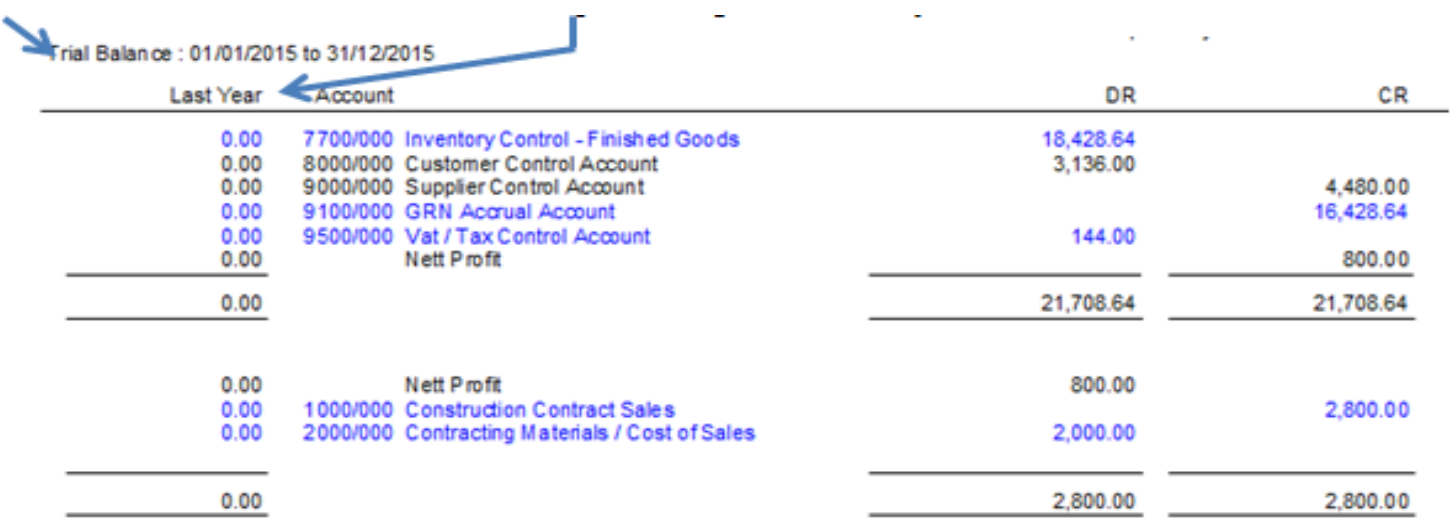

\section{Income Statement}

INCOME STATEME NT : 01/01/2015 to 31/12/2015

SALES

Construction Contrad Sales

COST OF SALES

Contracting M atenals / Cost of Sales

GROSS PROFIT / (LOSS)

OTHER INCOME

EXPENSES

TAX

DIMDENDS

NET PROFIT / (LOSS)

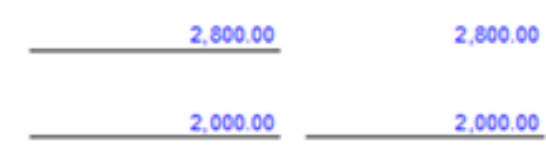

800.00

800.00

Balance Sheet

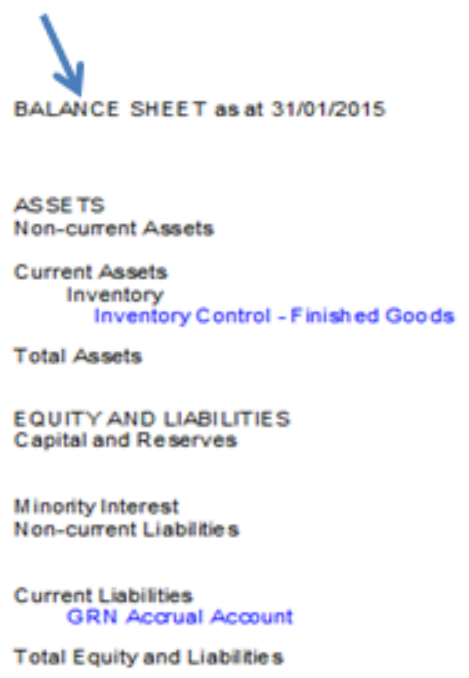

$2,434,32$ $2,434.32$

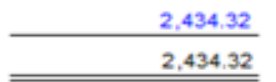

$2,434,32$

$2,434.32$

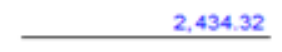

2, 434.32

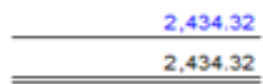


Cash Movement: This is for cash flow purposes

Cash Movement Report as at 31/12/2015 for 1 month(s)

\begin{tabular}{|c|c|c|}
\hline Peniod(s) & December & Total \\
\hline $\begin{array}{l}8400 / 000 \text { Main Account - Cash Book } \\
8410 / 000 \text { Account Name } \\
8420 / 000 \text { Account Name } \\
8430 / 000 \text { Account Name } \\
8440 / 000 \text { Account Name }\end{array}$ & & \\
\hline TOTAL OPENING BANK BALANCE & 0.00 & 0.00 \\
\hline $\begin{array}{l}\text { CASH RECE IVED } \\
\text { Receipts from Customers }\end{array}$ & 0.00 & 0.00 \\
\hline TOTAL RE CE IPTS & 0.00 & 0.00 \\
\hline $\begin{array}{l}\text { CASH PAID OUT } \\
\text { Payments to Suppliers }\end{array}$ & 0.00 & 0.00 \\
\hline TOTAL PAMMENTS & 0.00 & 0.00 \\
\hline NET CASH MOVE MENT & 0.00 & 0.00 \\
\hline JOURNAL ENTRIES PROCESSED & 0.00 & 0.00 \\
\hline TOTAL CLOSING BANK BALANCE & 0.00 & 0.00 \\
\hline
\end{tabular}

Graphs: The feature provides with all the graphs that may be needed by the accountant.

With a click of this icon a graph will be produced from the applications.

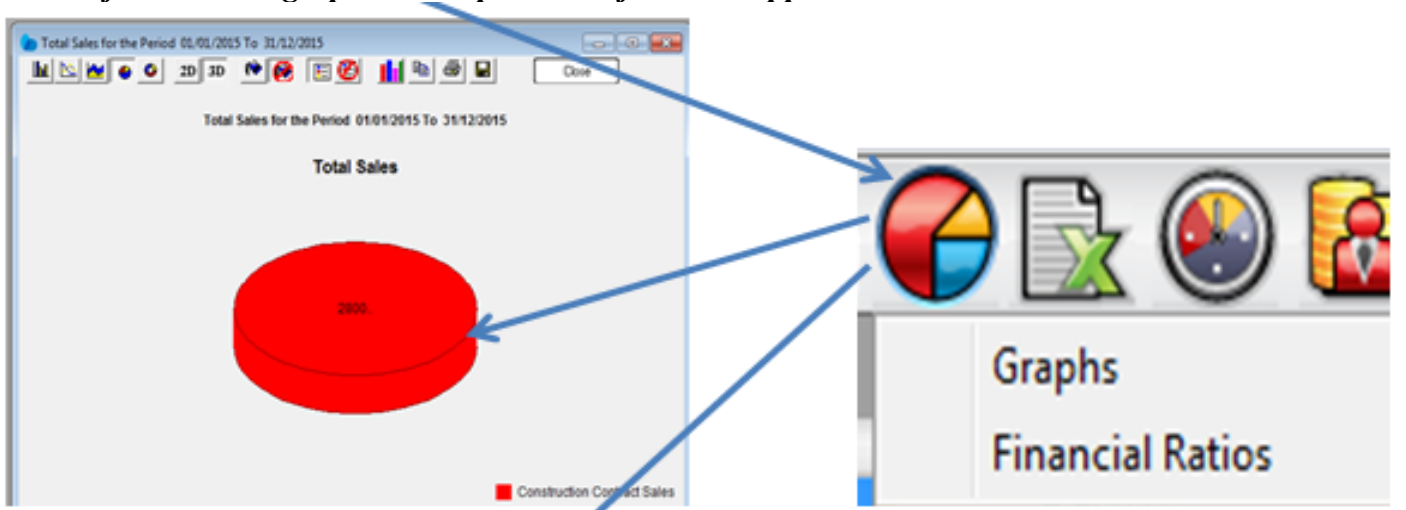

Financial Ratios: with a click of this icon important financial ratios below are generated by the software.

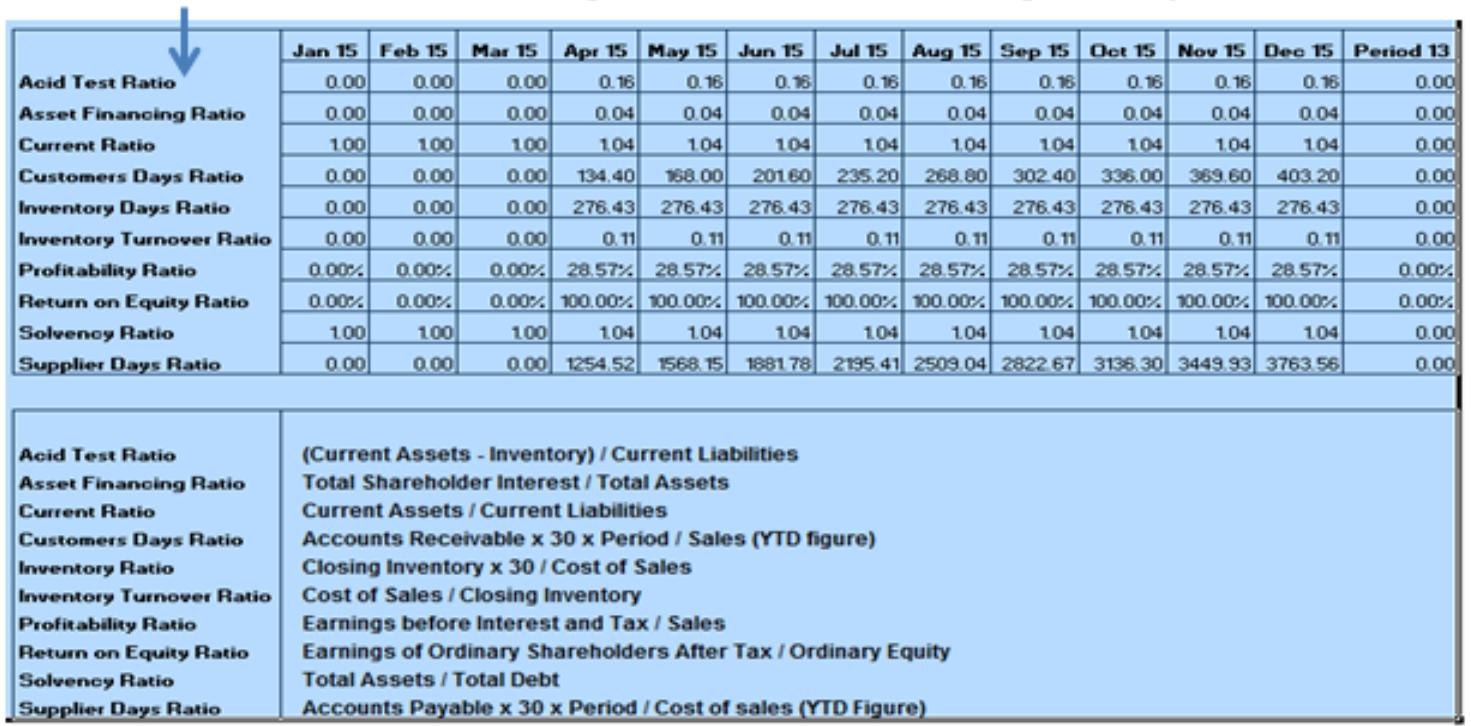


Business Intelligence Center Dashboard: This shows top and bottom items in the business.

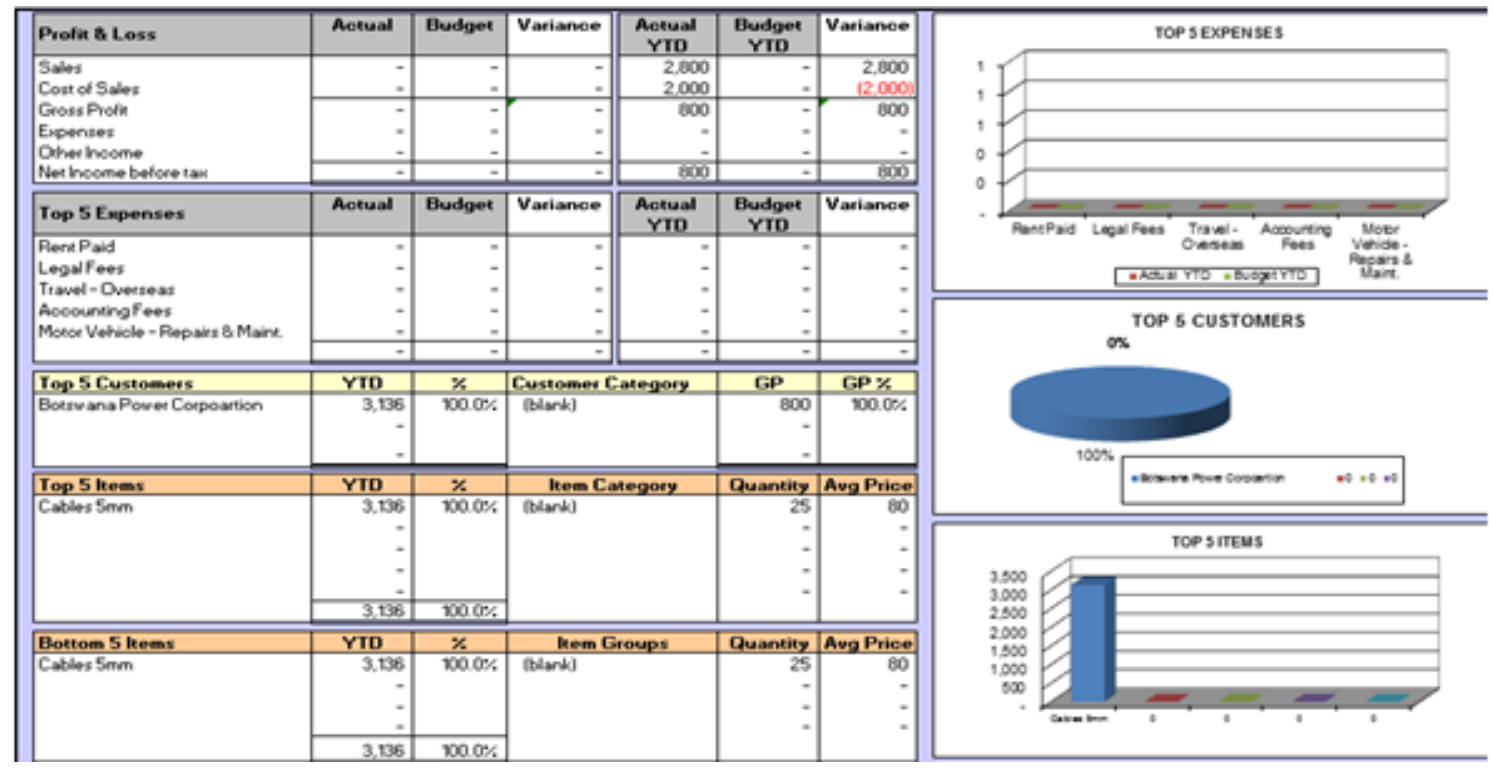

\subsubsection{Spreadsheets as Complimentary to Sage Pastel Accounting}

Sage Pastel Accounting is the application that was ranked highest with participants in [4] study. Spreadsheets are widely used throughout the whole world, either with accountants, engineers and many other professions. In this paper it is seen that most of the reports from Sage Pastel Accounting software automatically convert into spreadsheets reports. When using Sage Pastel Accounting users may import and export figures using spreadsheets. See features above such as graphs, financial ratios and the dashboard which has been imported or exported from Sage Pastel Accounting software.

\subsection{Statement of the Problem}

There has been an outcry in commerce and industry that the graduates for accounting are failing to perform and this cost them a lot of money and time through induction and training. Most of the reasons gathered from commerce and industry are that the accounting students lack the skills and knowledge that are expected of them especially the use of accounting package. It is therefore perceived that the accounting students understand the theory aspects but lack on the following practical areas: problem solving, analytical thinking and application and use of accounting packages (software). It is from this background that motivated the researchers into investigating whether the implementation of accounting software curriculum enhances students' practical technical skills, problem - solving skills and analytical thinking skills that are expected of by commerce and industry.

\subsection{Aim of the Study}

To investigate the perceptions of the students towards the implementation of Computerised accounting curriculum in order to enhance the accounting programme.

\subsection{Objectives of the Study}

The objectives of this study are as follows:

- To ascertain students' perceptions towards the implementation of Computerised Accounting curriculum.

- To identify the benefits that accrues from the implementation of Computerised Accounting curriculum.

- To recommend an inclusive curriculum that takes cognisance of problem - solving, analytical thinking and application and use of accounting packages (software).

\subsection{Research Questions}

The following are the research questions for this study:

- What are students' perceptions towards the implementation of Computerised Accounting curriculum?

- What are the benefits that accrue from the implementation of Computerised Accounting curriculum?

- What are the recommendations for an inclusive curriculum that takes cognisance of problem solving, analytical thinking and application and use of accounting packages (software)?

\subsection{Contribution to the Knowledge Domain}

The significance of this study is that, it would benefit many stakeholders that include: educators in the accounting field, accounting students, universities, colleges and captains 
of industry. The implementation of an inclusive curriculum that takes cognisance of practical skills will reduce costs of training for prospective employers. Furthermore, the graduates of accounting programme will be hands - on hence may be able to: set - up their own consulting firms and reduce the level of unemployment. If this study is published it would add value to the body of knowledge as it improves and enhances the practical skills for accounting students.

\section{Literature Review}

\subsection{The Importance of Capstone}

According to [12] many universities and colleges offer capstone course in the form of: an individual course, internship, volunteer or out-reach experience, consultation, research project, academic professional partnership or a combination of several experiences. In the context of this study, a capstone is viewed into two aspects as follows: individual course and internship experiences. The students at Botho University are placed on internship during semester 7 after learning all the theory aspects expected of an accounting student. Based on the study conducted by [3] they appear to be a skills gap in Botho University's Accounting Programme, as students are not taught Computerised Accounting Skills. A Computerised Accounting module involves teaching students practical skills which are beyond the classroom. According to [18] modules that teach students practical skills are outcome based. Outcome - based modules enables the learners and the instructors in getting constructive feedback on what the learner can do after the completion of each out - come hence this phenomenon enhances the learners to be hands-on (learning by doing, refer to Figure 2). The philosophy that promotes hands- on learning increases the learners' degree of employability and chances for becoming a self - reliant individual.

\subsubsection{Individual Course as a Capstone}

This section discusses a capstone as an individual course or module in an Accounting Programme. [1] and [4] concluded that computer skills and accounting software applications must be taught to accountants and additional course materials should be taught in all accounting courses. The teaching of accounting software applications enhances and enriches education. There are similarities between this study and the study for [4] as follows: This study involves accounting degree students' feedback during their internship and the study for [4] involves accounting students who participated, before and after the internship and the aim for both studies were to determine the importance of practical computer skills to accounting students. The results in [4] study reveals that accounting students, faculty and certified public accountant firm recruiters believe that computer skills, accounting software, databases, email / internet, programming, spreadsheets and word processing were important skills to accounting students. There are many accounting applications and software but this study focuses on Quick Books, Sage Pastel Accounting and Spreadsheets.

\subsection{Out-come Based Education (Learning)}

Outcome - led curricula are increasingly relevant to modern accounting education as employers prefer accounting graduates who have hands on competencies. According to [12] many universities and colleges offer a capstone course in business or accounting. Outcome - based is a criterion or standard that is used to set against the success of the course and the learners' competencies at the end of the programme [18]. In education reflective practice refers to whereby students reflect on what has been taught during the entire course or programme. Reflection in education is not new as it was used in the studies conducted with many philosophers and educational scholars such as [8]; [5], [6]; [7]; [20]; and [16]. [14] discusses the role of reflection in the experiential learning cycle.

A reflection may be in the capstone module where students are required to reflect their past experiences in the entire programme [12]. According to [12] the structure of the capstone can be as follows; individual course, internship, volunteer, out-reach experience, consultation, research project, academic- professional partnership, or a combination of several experiences. Many studies on capstone courses were written by [13] and [9].

The theoretical framework that informs this study is [14] experiential learning, see Figure 2 below. 


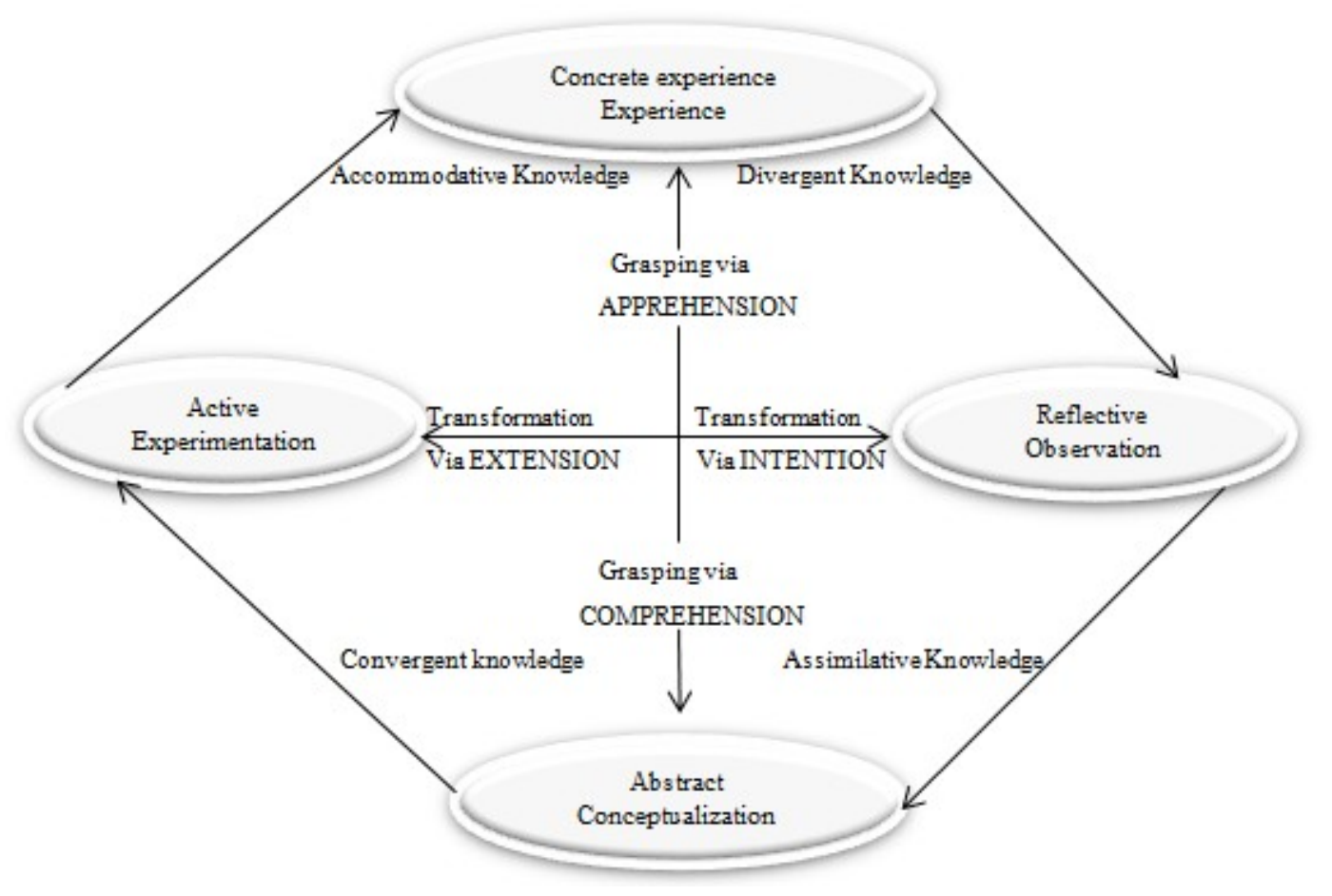

Figure 2. Kolb Model of Experiential Learning Process: (Adapted from Baker, Robinson and Kolb, 2012)

The study conducted by [3] concludes that experiential learning builds meta- cognitive skills which may be a goaloriented and assessed. (Experiential learning model see Figure 2) [14] of experiential learning assumes that the lecturers or teachers teach beyond the classroom in order to ensure that the learners are able to apply the concepts that are needed in the real- life situation. This concept of experiential learning may be used in many teaching approaches such as: field work, internships, simulations, vocational training and games [11]. This study focuses on the internship feedback of students who are studying a Bsc Hons in Accounting. It was imperative to investigate the gaps between what is being taught in classes and the actual applications of accounting concepts at the work place on internship students in order to enhance accounting programme at Botho University. In other words this was an evaluation of theme 4 (key skills) offered to accounting students. The following section focuses on the problem statement of this study.

\section{Research Methodology}

A research design is a plan which explains how a research would be conducted [17]. In this study a qualitative approach was used to collect data from the participants. The study used a focus group and face -to- face interviews as methods for collecting data from the students on internship registered in the Bsc Hons in Accounting at Botho University (semester 7, period July 2016 - December 2016. The following is a table that represents the internship population for three campuses (Gaborone, Francistown and
Maun).

Table 2. Botho University: Bsc Hons in Accounting - internship schedule

\begin{tabular}{|c|c|c|c|c|}
\hline Internship students & FTW & GBE & MAU & Total \\
\hline Total & 52 & 193 & 17 & 262 \\
\hline Percentage $\%$ & $20 \%$ & $74 \%$ & $6 \%$ & \\
\hline
\end{tabular}

No. of students on Internship per Campus

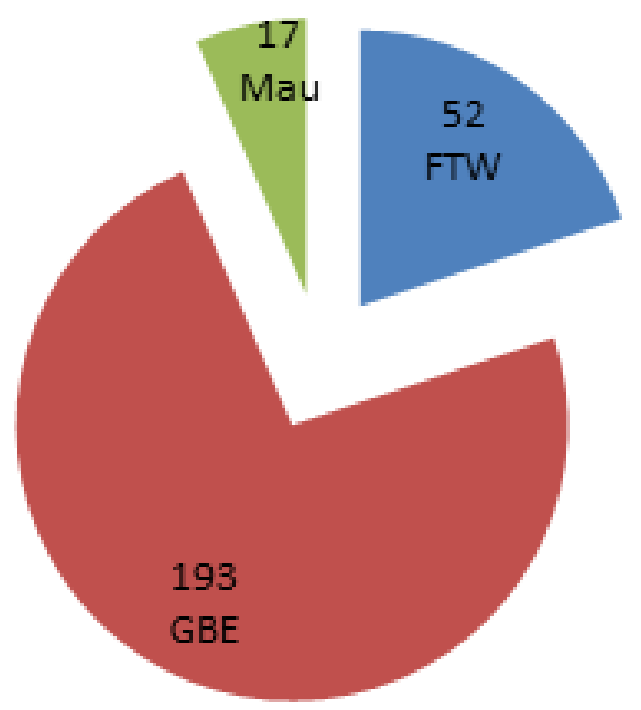

Graph 1. No. of students on internship per Campus

The focus group of 16 participants was selected from each campus based on the percentages shown in Table 2 above. The calculation for the sample is shown in Table 3 below. 
Table 3. Program version Enrollment: Bsc Hons in Accounting

\begin{tabular}{|c|c|c|c|c|}
\hline Campus & Percentage $-\%$ & Total focus & Calculations & Focus group per Campus \\
\hline FTW & $20 \%$ & 16 & $20 \% \times 16$ & 3 \\
\hline GBE & $74 \%$ & 16 & $74 \% \times 16$ & 12 \\
\hline MAU & $6 \%$ & 16 & $6 \% \times 16$ & 16 \\
\hline Total & & 16 & & 16 \\
\hline
\end{tabular}

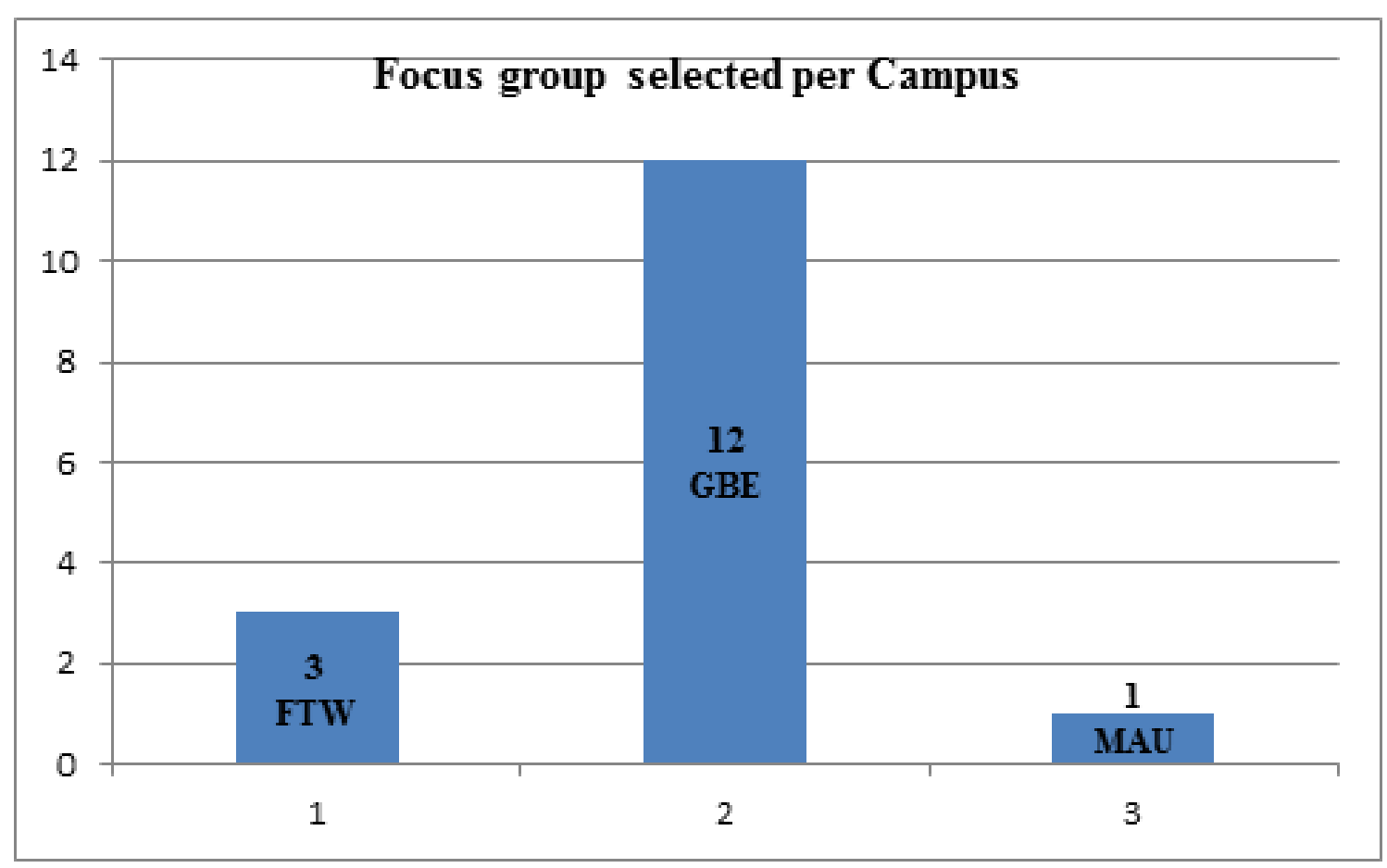

Graph 2. Focus group selected per campus

A brainstorming was conducted in order to conduct the participants about the focus group workshop.The researchers managed to get the students' consent to participate in this research.

According to [15] and [2] it is important to protect individual's autonomy hence researchers should not coerce any participant to participate in any study. Furthermore in this study the researchers did not divulge any confidential information to third parties without the participants' consent as this would be an infringement of the participants' rights to privacy. Finally names were not used in this study as each participant during the face -to- face interviews were allocated with codes.

\section{Results/Findings of the Study}

\subsection{Focus Group Workshop}

The following were the results from the focus group workshop: 
Table 4. Responses from focus group

\begin{tabular}{|c|c|}
\hline Questions & Responses from focus group \\
\hline $\begin{array}{l}\text { 4.1.2. The focus group participants } \\
\text { were asked that views towards the } \\
\text { implementation of a Computerised } \\
\text { Accounting Curriculum: }\end{array}$ & $\begin{array}{l}\text { All the participants agreed that a Computerised Accounting Curriculum enhance accounting } \\
\text { students' rate for employability traits and self - reliance (consultancy). The participants further } \\
\text { agreed that it was a challenge for most of them to be on internship without having attained } \\
\text { Computerised Accounting Skills. They perceived that most of the employers prefer students with } \\
\text { knowledge and skills in Computerised Accounting. Therefore the focus group appreciated and } \\
\text { welcomes the idea to implement a Computerised Accounting Curriculum as part of the Bsc Hons in }\end{array}$ \\
\hline $\begin{array}{l}\text { 4.1.3. The focus group was asked } \\
\text { whether there were any benefits that } \\
\text { accrue from an implementation of a } \\
\text { Computerised Accounting Curriculum: }\end{array}$ & $\begin{array}{l}\text { The participants agreed that there are many benefits that accrue from the implementation of a } \\
\text { Computerised Accounting Curriculum. The following are some of the benefit; } \\
\text { The users of a Computerised Accounting System adopt data entry processing skills that enhance the } \\
\text { speed for operating a computer. The users may easily adapt to cloud accounting and this enhances the } \\
\text { chances for getting consultancy work. }\end{array}$ \\
\hline $\begin{array}{l}\text { 4.1.4. The participants were asked } \\
\text { whether an inclusive curriculum takes } \\
\text { into account: problem - solving, } \\
\text { analytical thinking: }\end{array}$ & 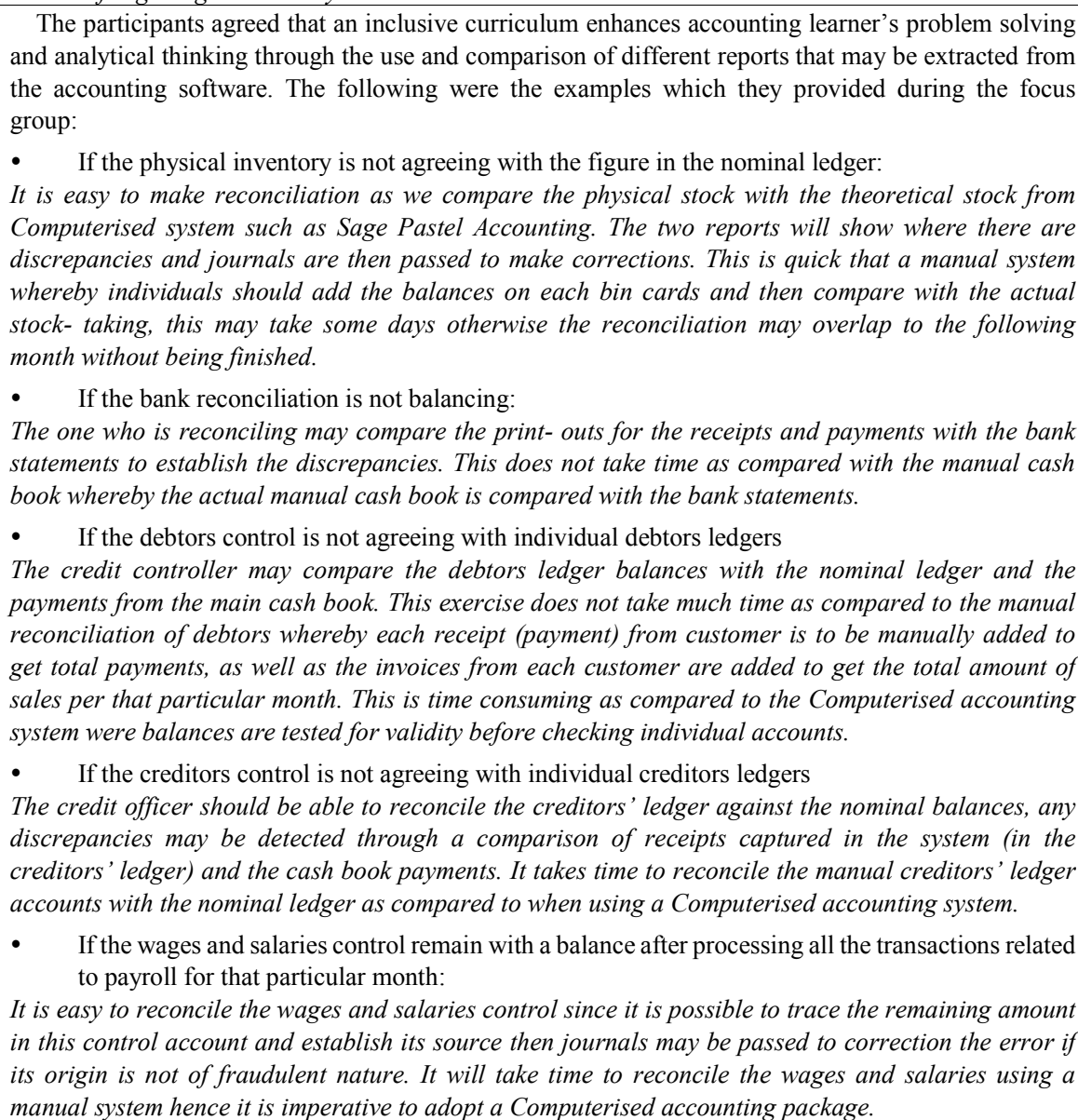 \\
\hline $\begin{array}{l}\text { 4.1.5. The following are computerised } \\
\text { accounting and other software that the } \\
\text { participants were comfortable to use: }\end{array}$ & $\begin{array}{l}\text { We are comfortable to use the following software as future accountants: Sage Pastel Accounting, } \\
\text { Quick- Books, Excel spreadsheets, Word processing and Power - point. }\end{array}$ \\
\hline
\end{tabular}

\subsection{Face -to- Face Interview}

The researchers used a face- to- face interview as a follow -up to the focus group workshop, to see whether the individual perceptions were agreeing with the group's perception towards the implementation of a computerised accounting Curriculum. The criteria used to select participants for face- to- face interview included 1 (one) internship student from each class (batch). This means that this convenient strategy included a representative in each class and campus, see Table 5.

Table 5. Participants for face to face interview and coding system (adapted from researchers)

\begin{tabular}{|c|c|c|c|c|c|c|c|c|c|}
\hline & Gaborone & & & & & & Francistown & Maun & Total \\
\hline & Batch 1 & Batch 2 & Batch 3 & Batch 4 & Batch 5 & Batch 6 & Batch 1 & Batch 1 & \\
\hline Number of students & 1 & 1 & 1 & 1 & 1 & 1 & 1 & 1 & 8 \\
\hline Participants' code & GAB01 & GAB02 & GAB03 & GAB04 & GAB05 & GAB06 & FTW01 & MAU01 \\
\hline
\end{tabular}




\subsubsection{Results for face- to- Face Interview}

The following were the results for the face-to face interview:

Participant: GAB01

What is your view towards the implementation of a Computerised Accounting Curriculum?

I welcome the implementation of a Computerised Accounting Curriculum in our Bsc Hons in Accounting. This system will assist me and my peers in gaining computer skills that are needed with employers. It was a challenge to work in the accounting department without these skills.

Which computerised accounting and other software that you are comfortable to use?

The most important software that I want to use during my entire life is Sage Pastel Accounting and Excel Spreadsheets.

Participant: GAB02

What is your view towards the implementation of a Computerised Accounting Curriculum?

The Computerised Accounting Curriculum is long over -due, we have been asking management every about its implementation. We have discovered that many employers prefer accounting graduates with who are knowledgeable of Sage Pastel Accounting, Quick Books or ACCPAC. Therefore we have seen during our internship that knowledge of any of the accounting packages is very important.

Which computerised accounting and other software that you are comfortable to use?

As I have mentioned in the earlier question I prefer any of the following accounting packages: Sage Pastel Accounting, Quick Books and ACCPAC.

Participant: GAB03

What is your view towards the implementation of a Computerised Accounting Curriculum?

I welcome the introduction of a Computerised Accounting Curriculum into our Accounting Programme. This curriculum will enhance our computer skills and add value to our Accounting Programme.

Which computerised accounting and other software that you are comfortable to use?

The following are the software that I am comfortable to use in the accounting department: Sage Pastel Accounting, Excel Spreadsheets and Power Point for presentations.

Participant: GAB04

What is your view towards the implementation of a Computerised Accounting Curriculum?

I welcome the implementation of a Computerised Accounting Curriculum and support this motion. Those students who do not support this idea are technophobia and they will have challenges working in an accounting environment as adaption of advanced technology is the right direction for future leaders.

Which computerised accounting and other software that you are comfortable to use?

I am comfortable working with Sage Pastel Accounting and Excel spreadsheets.

Participant: GAB05

What is your view towards the implementation of a Computerised Accounting Curriculum?

I like the idea for implementing a Computerised Accounting Curriculum in our Bsc Hons in Accounting as this enhances our Accounting Programme.

Which computerised accounting and other software that you are comfortable to use?

I am comfortable with Sage Pastel Accounting and Excel Spreadsheets.

Participant: GAB06

What is your view towards the implementation of a Computerised Accounting Curriculum?

This is a brilliant idea and during my internship I had some challenges working with Sage Pastel Accounting and Excel Spreadsheets. Therefore, implementing a Computerised Accounting Curriculum will assist especially during internship period and after completing the Accounting Programme as most employers assume that students are already exposed to any accounting package.

Which computerised accounting and other software that you are comfortable to use?

I am comfortable to work with Sage Pastel Accounting and Excel Spreadsheets as these are the most popular software with many employers.

Participant: FTW01

What is your view towards the implementation of a Computerised Accounting Curriculum?

I welcome the idea for implementing a Computerised Accounting Curriculum as it enhances our computer skills and communication skills. These are soft skills that are needed in commerce and industry.

Which computerised accounting and other software that you are comfortable to use?

I am comfortable to use Sage Pastel and Excel Spreadsheets.

Participant: MAU01

What is your view towards the implementation of a Computerised Accounting Curriculum?

I like this idea of implementing a Computerised Accounting Curriculum as it enhances critical, analytical thinking skills and problem - solving skills through the use of accounting packages.

Which computerised accounting and other software that you are comfortable to use? 
I am comfortable to use Sage Pastel, Power Point and Excel Spreadsheets.

In this study it has been shown that theme 4 (key skills see figure 1) is a fundamental aspect in the Bsc Hons in Accounting. Based on the students perceptions above it shows that Computerised Accounting Curriculum is critical to accounting students or graduates as it enhances the Accounting Programme hence its implementation is very important. In this day and age students should be exposed to a curriculum that requires them to learn by doing as confirmed in [14] experiential learning study (see figure 2) and Computerised Accounting Package is one of the module in Accounting that encourages learners to learn through doing (a concept of hands -on). Employers expect students or graduates who are well rounded and skilled. In an accounting environment the introduction of teaching a Computerised Accounting module is one of the best approaches to learning by doing. Therefore, an Accounting Programme should incorporate a concept that teaches students beyond class- room.

\section{A Detailed Plan for Participants' Reactions}

The participants described a detailed plan through their reactions which assist in the development of a practical curriculum for Sage Pastel Software as shown in figure 3.

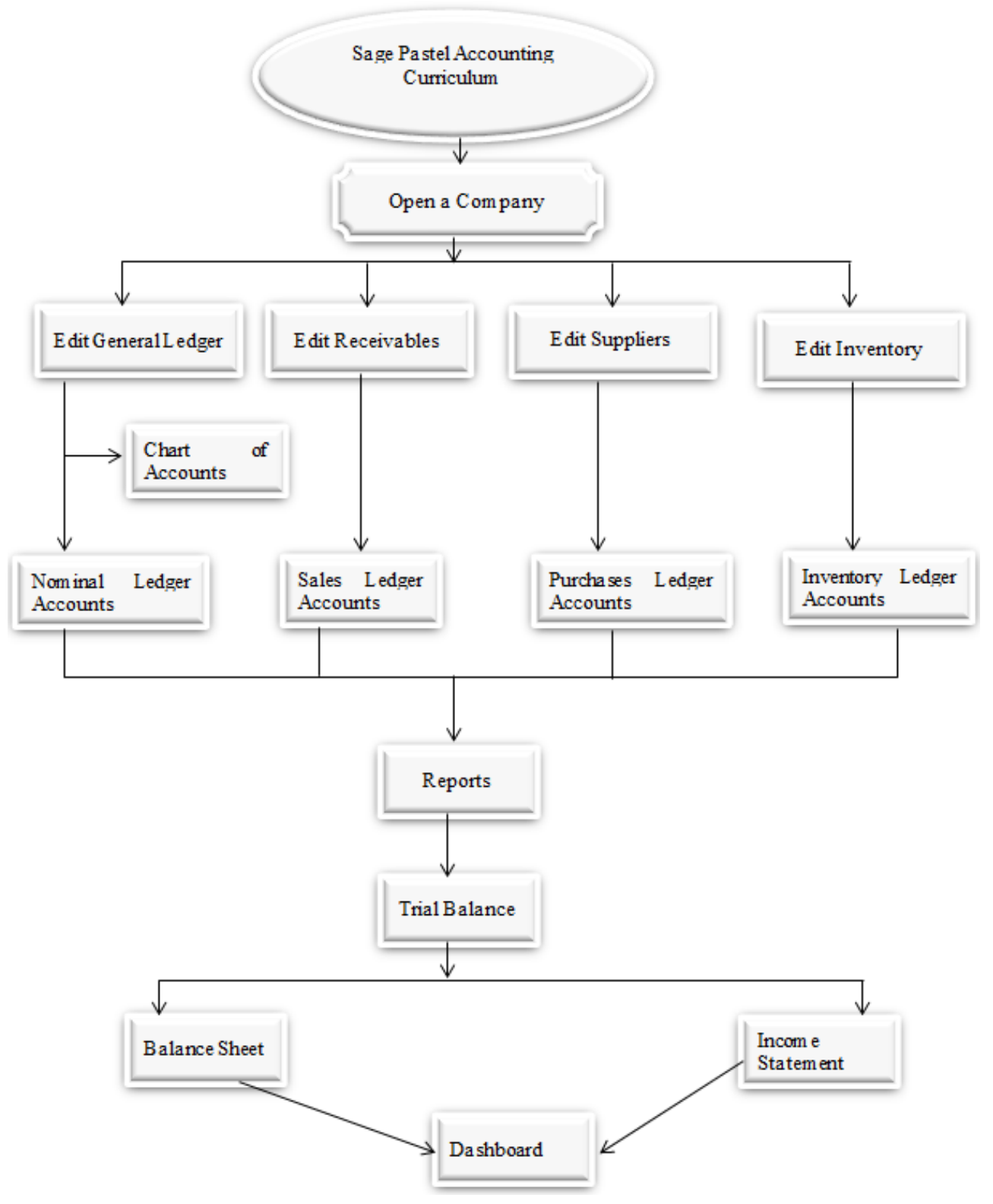

Figure 3. Sage Pastel Accounting Curriculum - Flow Diagram based on participants' reactions (adapted from the researchers) 
The above detailed plan assist accounting educators in developing a computerised accounting curriculum as this equip accounting students with practical skills that are needed in commerce and industry.

The following were detailed curriculum design and development strategies based participants' reactions:

When designing a computerised and developing an accounting curriculum the following stakeholders should be consulted as suggested by the participants (see table 6).

Table 6. Stakeholders to be involved when designing and developing a curriculum based on participants' reactions (Adapted from the researchers, 2016)

\begin{tabular}{|l|l|}
\hline \multicolumn{1}{|c|}{ Stakeholders } & \multicolumn{1}{|c|}{ Stakeholders' significance } \\
\hline 1) Students & - $\begin{array}{l}\text { It is imperative to involve the students in } \\
\text { designing and developing a curriculum for } \\
\text { computerised accounting. }\end{array}$ \\
\hline 2) Alumni & - $\begin{array}{l}\text { A tracer study to former students assist in } \\
\text { improving and closing the existing gaps. }\end{array}$ \\
\hline 3) Lecturers & - $\begin{array}{l}\text { Lecturers play a key role in developing and } \\
\text { designing a curriculum. }\end{array}$ \\
\hline $\begin{array}{l}\text { 4) Software } \\
\text { vendors }\end{array}$ & - $\begin{array}{l}\text { The vendors are important as they provide } \\
\text { with specifications and training and } \\
\text { development. }\end{array}$ \\
\hline $\begin{array}{l}\text { 5) Industry } \\
\text { forum }\end{array}$ & - $\begin{array}{l}\text { Industry provides with feedback on the } \\
\text { curriculum. }\end{array}$ \\
\hline 6) Government & - $\begin{array}{l}\text { Provide support and feedback to the entire } \\
\text { institution. }\end{array}$ \\
\hline
\end{tabular}

\section{Conclusions}

The results above show that both focus group workshop and face -to - face interview support the implementation of a Computerised Accounting Curriculum as it enhances an Accounting Programme. This module for Computerised Accounting assists students in mastering skills that are needed during the internship as well as in industry and commerce after the completion of the Accounting Programme. Therefore, if this module is implemented well it may increase the chances for employability and self reliance as the graduates will possess the required skills and knowledge that are needed in an accounting environment. The following were recommendations given if this module is introduced:

\section{Recommendations}

- Conduct workshops with the students so that they understand the importance and benefits for introducing the Computerised Accounting module in the Bsc Hons in Accounting Programme

- Accounting Programme should adopt a concept beyond the class- room (a concept of hands -on or learning by doing)

- Seek approval from Botho University Senior Management before implementation of the Computerised Accounting module
If the Computerised Accounting module is approved by Senior Management, submit for accreditation with Botswana Qualification Authority

- Pilot the implementation of the Computerised Accounting module first before introducing it to many students

- The assessments for this Computerised Accounting module should be practical in nature

- The teaching methodology of a Computerised Accounting module should be practical based and it is also important to involve the industry and accounting firms during the implementation of the curriculum

- Coordinate and collaborate with Sage Pastel Vendor (Suppler in South Africa) for detailed information

- Training of faculty members with a Certified Sage Pastel Facilitator

- Future studies:

- inquire from employers the relevance or the need for teaching a Computerised Accounting module to Accounting students

- comparison of performance for students who have been exposed to Computerised Accounting module and students not exposed to Computerised Accounting module

\section{REFERENCES}

[1] American Accounting Association. (1960). Report of the committee on the scope of the four year accounting major: Trends in undergraduate accounting education. The Accounting Review 35 (1): 203 -205.

[2] American Anthropological Association. 2012. Statement on Ethics: Principles of Professional Responsibilities. Available: http:// www.aaanet.org/coe/Code_of_Ethics.pdf. [2015, 22 January]

[3] Baker, M. A., and Robinson, J. S. (2012). Aligning Kolb's Experiential Learning Theory with a Comprehensive Agricultural Education Model. Journal of Agriculture Education 53 (40: 1- 16.

[4] Baker, W.B. (2013). Empirically Assessing the Importance of Computer Skills. Journal of Education for Business 88 (1): $345-351$

[5] Boud, D. (1999a). Situating Academic Development in Professional Work: Using Peer Learning. International Journal for Academic Development 4 (1): 3-10.

[6] Boud, D. (1999b). Avoiding the Traps: Seeking Good Practice in the Use of Self- Assessment and Reflection in Professional Courses. Social Work Education 18 (2): 121 -132 .

[7] Brookfield, S.D. (1987). Developing Critical Thinkers. San Francisco: Jossey - Bass Publishers.

[8] Dewey. (1933). How we think: A Restatement of the Relations of Reflective Thinking to Educative Process. 2nd rev. ed. Lexington, MA: DC Health Publishers. 
[9] Goldstein, G., \& Fernald, P. (2009). Humanistic education in a capstone course. College Teaching 57 (1): 27 -36.

[10] Green, B.P., Graybeal, P. and Madison, R, L. (2011). An Exploratory Study of the Effect of Professional Internships on Students' Perception of the Importance of Employment Traits. Journal of Education For Business 86 (1): 100-110.

[11] Itin, C. M. (1999). Reasserting the philosophy of experiential education as a vehicle for change in the $21^{\text {st }}$ century. Journal of Experiential Education 22 (2): 91 -98.

[12] Johnson, G, F. and Halabi, A, K. (2011). The Accounting Undergraduate Capstone: Promoting Synthesis, Reflection, Transition and Competencies. Journal of Education for Business 86 (1): 266 -273.

[13] Kerrigan, S., \& Jhaj, S. (2007). Assessing general education capstone courses. An in- depth look at a nationally recognised capstone assessment model. Peer Review 9 (2): 13-16.

[14] Kolb, D, A. (1984). Experiential Learning. Experience as a source of learning and development. Englewood Cliffs, N.J. Pretence Hall.
[15] Lucas, K., B. and Lidstone, J, G. (2000). Ethical issues in teaching about research eth1ics. Evaluation and Research in Education 14 (1): 51-72.

[16] McCormack, C., and Kennelly .R. (2011). We must Get Together and Really Talk...Connection, Engagement and Safety Sustain Learning and Teaching Conversation Communities. Reflective Practice 12 (4): 515- 531.

[17] Mouton, J. (2001). How to succeed in your Master's \& Doctoral Studies: A South African Guide and Resource Book. Pretoria: Van Schaik.

[18] Ross, N. and Davies, D. (1999). AMEE Guide No. 14: Outcome- based education: Part 4- Outcome - based learning and the electronic curriculum at Birmingham Medical School. Medical Teacher 21 (1): 26- 31.

[19] Sage Pastel Accounting Software Module . (2016). South Africa.

[20] Schon, D. A. (1983). The Reflective Practitioner. San Francisco: Jossey-Bass Publishers.

[21] WWW.QUICKBOOKS.CO.ZA 